\title{
IMPLEMENTASI KOMPONEN KETERAMPILAN MENGADAKAN VARIASI PADA PEMBELAJARAN PPKn DI KELAS VIII MTS AL-MUSTAQIM MABODO
}

\author{
Fitriani $^{1}$, Karsadi ${ }^{2}$, Hamuni $^{3}$ \\ Jurusan Pendidikan Pancasila dan Kewarganegaraan \\ Fakultas Keguruan dan Ilmu Pendidikan \\ Universitas Halu Oleo \\ Email:fitriani@gmail.com ${ }^{1}$, karsadi@gmail.com $^{2}$, hamuni@gmail.com $^{3}$
}

\begin{abstract}
Abstrak: Tujuan penelitian ini adalah (1) untuk mengetahui komponen keterampilan mengadakan variasi diimplementasikan pada pembelajaran PPKn di kelas VIII MTs AlMustaqim Mabodo, dan (2) untuk mengetahui hambatan dalam mengimplementasikan keterampilan mengadakan variasi pada pembelajaran PPKn di kelas VIII MTs AlMustaqim Mabodo. Penelitian ini adalah penelitian deskriptif dengan menggunakan pendekatan kualitatif. Subjek penelitian berjumlah 6 orang. Teknik pengumpulan data yaitu observasi, wawancara dan dokumentasi. Teknik analisis data sebagaimana yang dikemukakan oleh Miles dan Huberman yang terdiri dari: pengumpulan data, reduksi data, penyajian data, dan penarikan kesimpulan. Hasil penelitian menunjukkan (1) komponen keterampilan mengadakan variasi pada komponen variasi gaya mengajar masih terlihat cukup baik, pada proses pembelajaran PPKn di kelas VIII MTs Al-Mustaqim Mabodo, sedangkan komponen media pembelajaran masih sangat minim, terutama terlihat pada langkah-langkah kegiatan pembelajaran mengadakan variasi media pembelajaran. (2) hambatannya terlihat pada keterampilan mengadakan variasi dan pada pola interaksinya, terlihat masih lemahnya kemampuan guru dalam mengemas media pembelajaran yang menarik minat belajar siswa serta pada sarana dan prasarana terlihat masih sangat terbatas.
\end{abstract}

Kata Kunci: Keterampilan Mengadakan Variasi, Pembelajaran PPKn

\section{PENDAHULUAN}

Pendidikan merupakan faktor penting dalam mempersiapkan serta membangun bangsa dan negara agar mampu bersaing dengan negara di belahan dunia lainnya. Undang-Undang Republik Indonesia Nomor 20 Tahun 2003 tentang Sistem Pendidikan Nasional Pasal 1 ayat (1), pendidikan adalah usaha sadar dan terencana untuk mewujudkan suasana belajar dan proses pembelajaran agar peserta didik secara aktif mengembangkan potensi dirinya untuk memiliki kekuatan spiritual keagamaan, pengendalian diri, kepribadian, kecerdasan, akhlak mulia, serta keterampilan yang diperlukan dirinya, masyarakat, bangsa dan negara. Guru adalah pendidik profesional dengan tugas utama mendidik, mengajar, membimbing, mengarahkan, melatih, menilai dan mengevaluasi peserta didik pada pendidikan anak usia dini jalur pendidikan formal, pendidikan dasar, dan pendidikan menengah (Pasal 1 ayat (1) UU No 14/2005 tentang Guru dan Dosen). Dikaitkan dengan pembelajaran berbasis kompetensi, keterampilan dasar sangat penting untuk dikuasai oleh guru. Sebab strategi dan model pembelajaran apa pun yang digunakan efektivitasnya sangat ditentukan oleh keterampilan guru dalam pengelolaan proses pembelajaran. Ada sejumlah keterampilan yang harus dimiliki seorang guru agar dalam mengerjakan tugas profesionalnya berhasil secara optimal sehingga mutu pendidikan dapat terwujud dengan baik. 
Menurut Solihatin (2013:58-76), terdapat 8 keterampilan dasar mengajar yang dianggap berperan penting dalam menentukan keberhasilan pembelajaran. Keterampilan yang dimaksud adalah: (1) keterampilan bertanya, (2) keterampilan memberikan penguatan, (3) keterampilan mengadakan variasi, (4) keterampilan menjelaskan, (5) keterampilan membuka dan menutup pembelajaran, (6) keterampilan membimbing diskusi kelompok kecil, (7) keterampilan mengelola kelas, (8) keterampilan mengajar perseorangan. Pelaksanaan proses pembelajaran seharusnya menekankan pada pemberian pengalaman langsung, kontekstual dan berpusat kepada siswa. Oleh sebab itu, guru harus mampu mengadakan variasi pembelajaran agar siswa lebih kreatif dan tidak bosan dalam menerima pembelajaran. Berdasarkan hasil observasi awal di kelas VIII sekolah MTs AlMustaqim Mabodo Kecamatan Kontunaga Kabupaten Muna di temukan bahwa pelaksanaan proses pembelajaran di kelas belum optimal, guru tidak membawa perangkat pembelajaran di kelas, masih dominan menggunakan metode ceramah dan belum menempuh langkah-langkah pendekatan saintifik secara baik dalam proses pembelajaran, terlihat sebagian besar siswa keluar masuk kelas saat pembelajaran berlangsung, siswa tidak aktif belajar, pembelajaran masih bersifat konvensioanal dimana guru masih sering menggunakan media papan tulis dan tidak kreaktif menggunakan media atau alat peraga dalam membawakan materi pelajaran sehingga pembelajaran tidak menarik, siswa tidak termotivasi (jenuh) untuk belajar.

\section{Keterampilan Mengadakan Variasi}

Menurut Solihatin (2013:61), Variasi dalam kegiatan pembelajaran adalah perubahan dalam proses kegiatan yang bertujuan untuk meningkatkan motivasi siswa, serta mengurangi kejenuhan dan kebosanan. Menurut Djamarah (2010: 9396) keterampilan dalam mengadakan variasi dalam kegiatan pembelajaran dapat dikelompokkan menjadi 3 bagian, yaitu:

1) Variasi gaya mengajar,

Dapat dilakukan dengan berbagai cara seperti: a) Variasi suara: Suara guru dapat bervariasi dalam: Intonasi, nada, volume, dan kecepatan. Guru dapat mendramatisasi suatu peristiwa dengan menunjukkan hal- hal yang dianggap penting, berbicara secara pelan dengan seorang anak didik, atau berbicara secara tajam dengan anak didik yang kurang perhatikan, dan seterusnya.; b) Penekanan (focusing): Untuk menfokuskan perhatian anak didik pada suatu aspek yang penting atau aspek kunci, guru dapat menggunakan "penekanan secara verbal", misalnya: "perhatikan baik- baik! ", "ini bagian yang sukar, dengarkan baik- baik." Penekanan seperti itu biasanya dikombinasikan dengan gerakan anggota badan; c) Pemberian waktu (pausing): Untuk menarik perhatian anak didik dapat dilakukan dengan mengubah suasana menjadi sepi, dari suatu kegiatan menjadi tanpa kegiatan/ diam, dari akhir bagian pelajaran ke bagian berikutnya; d) Kontak pandang: Bila guru sedang berbicara atau berinteraksi dengan siswanya, sebaiknya mengarahkan pandangannya ke seluruh kelas menatap mata setiap siswa untuk menunjukkan adanya hubungan yang positif dengan mereka. Kontak pandang dapat digunakan untuk menyampaikan informasi dan untuk mengetahui perhatian atau pemahaman siswa; e) Gerakan anggota badan (gesturing): Variasi dalam mimik, gerakan kepala atau gerakan badan merupakan bagian penting dalam berkomunikasi. Gunanya untuk menarik perhatian dan untuk menyampaikan arti 
dari pesan lisan yang dimaksudkan. Ekspresi wajah misalnya tersenyum, mengerutkan dahi, cemberut, menaikkan alis mata, untuk menunjukkan kagum, tercengang, atau heran. Gerakan kepala dapat dilakukan dengan bermacammacam, misalnya menganggukkan, menggeleng, mengangkat, atau merendahkan kepala untuk menunjukkan setuju atau sebaliknya. Jari dapat digunakan untuk menunjukkan ukuran, jarak arah ataupun menjentik untuk menarik perhatian; dan f) Pergantian posisi guru di dalam kelas: Pergantian posisi guru di dalam kelas dapat digunakan untuk mempertahankan perhatian siswa. Dalam menyajikan pelajaran di dalam kelas, biasakan bergerak bebas, tidak kikuk atau kaku, dan hindari tingkah laku negatif.

2) Variasi media dan bahan pembelajaran,

Variasi media dan bahan pembelajaran dapat berupa: a) Dengan menggunakan variasi media pandang seperti menggunakan gambar, slide, foto, bagan, dan lain-lain; b) Variasi media dengar seperti menggunakan radio, musik, deklamasi, puisi, dan lain sebagainya; dan c) Variasi media taktil yaitu alat atau bahan yang dapat diraba, dimanipulasi, dan di gerakkan. Pemanfaatan media semacam ini dapat menarik perhatian siswa, sebab siswa dapat secara langsung membentuk atau memperagakan kegiatannya, baik secara perorangan ataupun secara kelompok.

d) Variasi pola interaksi,

Variasi dalam pola interaksi antara guru dan anak didik memiliki rentangan yang bergerak dari dua kutub, yaitu: a) Anak didik bekerja atau belajar secara bebas tanpa campur tangan dari guru; dan 2) Anak didik mendengarkan dengan pasif. Situasi didominasi oleh guru, di mana guru berbicara kepada anak didik.

\section{Tujuan, Manfaat dan Prinsip Penggunaan Keterampilan Mengadakan Variasi}

\section{Tujuan Penggunaan Keterampilan Mengadakan Variasi}

Menurut Djamarah (2010: 161) penggunaan variasi terutama ditujukan terhadap perhatian siswa, motivasi, dan belajar siswa. Tujuan mengadakan variasi yaitu: a) meningkatkan dan memelihara perhatian siswa terhadap relevansi proses belajar mengajar, b) memberikan kesempatan kemungkinan berfungsinya motivasi, c) membentuk sikap positif terhadap guru dan sekolah, d) memberikan kemungkinan pilihan dan fasilitas belajar individual, e) mendorong anak didik untuk belajar.

\section{Manfaat Keterampilan Mengadakan Variasi}

Menurut Hermawan (Permatasari, 2016: 48) manfaat mengadakan variasi pembelajaran antara lain sebagai berikut: 1) Menumbuhkan dan meningkatkan motivasi dan perhatian siswa terhadap tema pembelajaran yang dibahas, dan keterkaitan di dalam yang ada dalam tema tersebut; 2) Memberikan kesempatan kepada siswa untuk mengembangkan rasa ingin tahu tentang sesuatu yang baru dalam suatu tema yang dipelajarinya; 3) Memupuk perilaku positif siswa terhadap guru yang telah melakukan proses pembelajaran dengan lebih hidup dan bervariasi; 4) Menghindarkan siswa dari proses pembelajaran yang membosankan dan monoton; 5) Meningkatkan kadar keaktifan dan keterlibatan siswa dalam berbagai pengalaman pembelajaran yang menarik dan terarah; dan 6) Melayani karakteristik siswa dan gaya belajarnya yang beraneka ragam. 


\section{Prinsip Penggunaan Keterampilan Mengadakan Variasi}

Menurut Djamarah (2010: 125) prinsip penggunaan variasi yaitu: a) dalam menggunakan keterampilan variasi sebaiknya semua jenis variasi digunakan, b) menggunakan variasi secara lancar dan berkesinambungan, c) penggunaan komponen variasi harus benar-benar terstruktur dan direncanakan oleh guru.

\section{Hambatan Yang Dihadapi Guru Dalam Mengimplementasikan Keterampilan mengadakan Variasi}

Hambatan yang dihadapi guru dapat dilihat dari faktor-faktor yang berpengaruh terhadap pembelajaran dan komponen pembelajaran, Wina Sanjaya (2006: 52) menyatakan bahwa faktor-faktor pembelajaran meliputi (1) guru, (2) siswa, (3) sarana dan prasarana, dan (4) lingkungan. Lebih lanjut menurut Sanjaya (2006: 52-57), hambatan yang dihadapi terlihat ketika guru mengalami kesulitan untuk mendapatkan media yang lebih bervariasi namun masih berhubungan dengan materi yang sedang dijelaskan. Sejauh ini guru hanya menggunakan fasilitas yang ada di kelas seperti spidol, papan tulis, dan suara guru itu sendiri. Selain itu, guru juga mengalami hambatan dilihat dari segi sarana dan prasarana. Dalam proses pembelajaran, masih banyak guru yang hanya melakukan tugas sebatas mentransfer ilmu tanpa tahu bagaimana mengemas pembelajaran menjadi menarik perhatian siswa, sehingga banyak ditemui siswa yang kurang memiliki motivasi untuk lebih giat belajar di sekolah.

\section{METODE PENELITIAN}

Pendekatan yang digunakan dalam penelitian ini adalah pendekatan kualitatif. Subjek penelitian ini adalah guru PPKn satu orang selaku responden, kepala sekolah MTs Al-Mustaqim Mabodo dan 4 orang siswa masing-masing selaku informan. Teknik dalam pengumpulan data yang digunakan adalah: 1) Penelitian kepustakaan; 2) Penelitian lapangan, terdiri dari: wawancara dan dokumentasi. Teknik analisis data menggunakan data kualitatif yakni Data Reduction (Reduksi Data); Data Display (Penyajian Data); dan Conclution Drawing/Verivication (Penarikan Kesimpulan). Miles dan Huberman (Sugiyono, 2014).

\section{HASIL PENELITIAN DAN PEMBAHASAN}

\section{Komponen Keterampilan Mengadakan Variasi Yang Diimplementasikan} Pada Pembelajaran PPKn di Kelas VIII MTs Al-Mustaqim Mabodo

\section{1) Variasi Gaya Mengajar}

Variasi gaya mengajar merupakan perubahan gaya mengajar yang dilakukan oleh guru dalam proses pembelajaran saat menjelaskan atau menyampaikan materi pelajaran. Variasi gaya mengajar di kelas meliputi variasi suara, penekanan/memusatkan perhatian, pemberian waktu/pausing, kontak pandang, gerakan anggota badan dan pergantian posisi guru di dalam kelas.

a) Variasi Suara

Berdasarkan data hasil penelitian menunjukkan bahwa implementasi keterampilan mengadakan variasi suara cukup baik. Data menunjukkan guru PPKn MTs Al-Mustaqim Mabodo mengimplementasikan semua indikator variasi suara dalam pembelajaran dilaksanakan dengan cara: (1) suara guru tidak monoton, (2) 
guru memberikan tekanan suara pada point-point penting, (3) suara guru jelas didengar siswa dan (4) guru memperhatikan intonasi suara.

b) Penekanan Suara/Memusatkan Perhatian

Berdasarkan data hasil penelitian menunjukkan bahwa implementasi variasi penekanan suara/memusatkan perhatian, guru PPKn mengimplementasikan variasi ini dengan cara: (a) guru memusatkan perhatian siswa melalui penekanan suara seperti anak- anak tolong semuanya tenang, dengarkan dan perhatikan baik-baik yang ibu sampaikan karena ini point-point penting yang harus kalian pahami mengenai materi ini, (2) guru menjelaskan/menyampaikan materi pelajaran dengan sangat lancar dan mudah dimengerti oleh siswa, dan (3) guru menggunakan katakata yang mudah dipahami siswa. Ada satu komponen variasi penekanan suara/menusatkan perhatian yang tidak dilaksanakan oleh guru yaitu keterampilan menggunakan penekanan suara secara verbal.

c) Pemberian Waktu/Pausing

Berdasarkan data hasil penelitian menunjukkan bahwa guru PPKn MTs AlMustaqim Mabodo dalam mengimplementasikan variasi pemberian waktu/pausing cukup baik. Guru PPKn melaksanakannya dengan cara: (a) pada saat kegiatan pembelajaran guru diam secara tiba-tiba, (b) guru memberikan waktu kepada siswa untuk berpikir, dan (c) guru memberi jeda saat siswa bertanya dan juga memberikan waktu kepada siswa untuk berpikir ketika guru mengajukan pertanyaan seputar materi yang sedang dipelajari, tetapi karena siswa belum memegang atau dibagikan buku siswa maka guru belum melaksanakan aspek meminta siswa membaca didalam hati.

d) Kontak Pandang

Berdasarkan data hasil penelitian menunjukkan bahwa guru PPKn MTs AlMustaqim Mabodo dalam mengimplementasikan variasi kontak pandang cukup baik, guru PPKn mengimplementasikan variasi kontak pandang dengan cara: (a) membagi pandangannya kepada seluruh siswa, (b) saat ada siswa yang bertanya guru melihat kearah siswa dan (3) saat menjelaskan pun guru selalu memperhatikan seluruh siswa dan jika ada yang kurang kosentrasi guru langsung menegurnya. Namun guru tidak menyentuh bahu siswa yang kurang perhatian, guru hanya menegurnya saja.

e) Gerakan Anggota Badan

Berdasarkan data hasil penelitian menunjukkan bahwa guru PPKn MTs AlMustaqim Mabodo dalam mengimplementasikan variasi gerakan anggota badan sangat baik, dimana guru PPKn mengimplementasikannya dengan cara: memasang wajah semangat, menunjuk siswa yang kurang perhatian dan mengarahkannya agar memerhatikan ketika guru ataupun temannya yang sedang presentasi depan kelas, juga menganggukan kepala ketika mendengar jawaban ataupun pertanyaan dari siswanya.

f) Pergantian Posisi Guru dalam Kelas

Berdasarkan data hasil penelitian menunjukkan bahwa guru PPKn MTs AlMustaqim Mabodo dalam mengimplementasikan variasi pergantian posisi guru di dalam kelas sangat baik, dimana guru PPKn mengimplementasikannya dengan cara: (a) guru tidak berada dalam satu posisi, (b) pergantian posisi guru tidak kaku, (c) guru berjalan mendekati dan menjauhi siswa ketika sedang menjelaskan dan dalam membentuk kelompok dan (d) guru mengitari ruangan dalam kelas. 


\section{2) Variasi Media Pembelajaran}

Penggunaan media dalam proses pembelajaran sangat efektif untuk menarik perhatian siswa, agar pembelajaran tidak terkesan monoton. Media yang dapat digunakan untuk menyampaikan pesan seperti penggunaan media gambar, peta, video, rekaman audio dan lain-lain sesuai dengan materi yang diajarkan.

1) Variasi Media Pandang

Berdasarkan data hasil penelitian menunjukkan bahwa guru PPKn dalam mengimplementasikan variasi media pandang masih kurang baik karena (1) guru tidak menggunakan media gambar, slide, foto dan bagan, (2) guru tidak menjelaskan media yang akan digunakan, dan (3) guru juga tidak menggunakan film dalam menyampaikan materi. Namun guru menjadikan siswa sebagai model saat menyuruh siswa untuk tampil presentasi di depan kelas. Media tidak menarik perhatian siswa dan bahkan dalam pembelajaran tidak jarang terlihat ada siswa yang sering menguap, karena dalam proses pembelajaran guru belum kreatif dalam membuat media pelajaran yang dapat menarik perhatian siswa, dalam mengajar guru hanya mengandalkan buku paket, spidol dan papan tulis saja.

2) Variasi Media Dengar

Berdasarkan data hasil penelitian menunjukkan bahwa guru PPKn masih kurang baik dalam mengimplementasikan variasi media dengar karena guru hanya menggunakan suaranya sebagai media dengar saat menjelaskan materi pelajaran. Guru tidak menggunakan radio, musik, rekaman atau alat elektronik dalam mengimplementasikan variasi media dengar.

3) Variasi Media Taktil/ yang dapat diraba

Berdasarkan data hasil penelitian menunjukkan bahwa guru PPKn kurang baik dalam mengimplementasikan variasi media taktil atau yang dapat diraba. Guru PPKn hanya mengarahkan siswa untuk tampil di depan kelas. Namun, guru tidak mengarahkan siswa untuk menjelaskan suatu gambar atau bagan karena guru tidak menggunakan media lain selain buku, spidol dan papan tulis, ketika tampil di depan kelas siswa hanya membaca hasil kerjanya dan tidak menjelaskan menggunakan spidol untuk menunjuk materi pelajaran di papan tulis.

\section{3) Variasi Pola Interaksi}

Pola interaksi merupakan faktor penting dalam keberhasilan pembelajaran. Adanya pola interaksi yang baik dan lancar dimana guru tidak selalu mendominasi dalam kelas maka akan membuat suasana belajar menjadi lebih aktif dan siswa merasa terlibat dan diperhatikan guru dalam proses pembelajaran.

a) Anak didik bekerja/belajar secara bebas

Berdasarkan data hasil penelitian menunjukkan bahwa anak didik bekerja/belajar secara bebas masih kurang baik dilaksanakan, aspek yang diamati point (1) belum dilaksanakan karena siswa kurang kompak bekerja dalam kelompok dan aspek yang diamati point (2) dilaksanakan karena guru menyuruh tiap perwakilan kelompok untuk maju presentasi di depan kelas.

b) Anak didik mendengarkan dengan pasif

Berdasarkan data hasil penelitian menunjukkan bahwa guru PPKn mengimplementasikan variasi ini dengan cara membentuk variasi kelompok diskusi menjadi tiga kelompok, masing-masing kelompok menjawab satu tujuan pembelajaran dan guru membangun interaksi siswa dengan siswa. 


\section{Hambatan Dalam Mengimplementasikan Keterampilan Mengadakan Variasi Pada Pembelajaran PPKn di kelas VIII MTs Al-Mustaqim Mabodo} 1) Hambatan dari segi variasi gaya mengajar

Terdapat enam indikator pada variasi gaya mengajar yaitu variasi suara, penekanan suara/ memusatkan perhatian siswa, pemberian waktu (pausing), kontak pandang, gerakan anggota badan, dan pergantian posisi guru, meskipun semua indikator hampir sempurna dilaksanakan oleh guru namun ternyata guru juga masih mengalami kendala.Berdasarkan hasil penelitian menunjukkan bahwa guru PPKn dalam melaksanakan variasi gaya mengajar menghadapi hambatan pada indikator (a) penekanan suara/memusatkan perhatian siswa dan (b) pemberian waktu berpikir karena sebagian siswa sulit di atur dan guru PPKn sulit membuat siswa untuk berani berbicara dan atau untuk bertanya mengenai materi pelajaran meskipun guru sudah memotivasinya.

\section{2) Hambatan dari segi variasi penggunaan media pembelajaran}

Pertama, hambatan yang dihadapi guru PPKn mengimplementasikan variasi media pandang dengar adalah penggunaan alat bantu film, gambar, slide dan foto yang mendukung materi belum terlaksana karena masih kurangnya sarana dan prasarana sekolah seperti proyektor dan listrik dan guru belum dapat membuat media gambar atau menunjukkannya kepada siswa sehingga pembelajaran kurang menarik. Kedua, hambatan yang dihadapi guru PPKn mengimplementasikan variasi media dengar adalah penggunaan alat bantu/media radio dan musik, rekaman materi pelajaran dan penggunaan alat elektronik belum terlaksana karena masih kurangnya sarana dan prasanara sekolah dan guru hanya menggunakan suaranya dalam menyampaikan materi sebagai media dengar. Ketiga, hambatan yang dihadapi guru PPKn mengimplementasikan variasi media taktil adalah karena guru hanya membentuk kelompok diskusi dan siswa maju ke depan kelas memperagakan atau mempresentasikan hasil kerja kelompoknya.

Dalam melaksanakan pembelajaran guru hanya menggunakan fasilitas dan media seadanya seperti buku, spidol, papan tulis dan suara guru itu sendiri.

\section{3) Hambatan dari segi variasi pola interaksi}

Hambatan yang dihadapi guru PPKn mengimplementasikan variasi pola interaksi adalah kurangnya kekompakan siswa dalam kelompok diskusi, ada sebagian siswa terlihat pasif dalam kelompok walaupun guru sudah memberikan tugas dari setiap siswa, kurang bekerja sama dan hanya beberapa siswa saja yang mengerjakannya sedangkan yang lain hanya diam saja, dan kurangnya percaya diri siswa untuk tampil di depan kelas.

\section{PENUTUP}

\section{Kesimpulan}

Berdasarkan hasil penelitian dan pembahasan, dapat ditarik kesimpulan sebagai berikut:

1) Bahwa komponen keterampilan mengadakan variasi di kelas VIII MTs AlMustaqim Mabodo, pada komponen variasi gaya mengajar guru PPKn sudah mengimplementasikannya dengan cukup baik, pada komponen variasi media pembelajaran guru PPKn masih belum maksimal dalam mengimplementasikannya karena guru PPKn hanya menggunakan buku paket, spidol, papan tulis dan suara guru itu sendiri serta penampilan presentasi siswa 
di depan kelas sebagai media dan pada variasi pola interaksi guru masih belum maksimal melaksanakannya.

2) Hambatan dalam mengimplementasikan keterampilan mengadakan variasi pada variasi gaya mengajar ada dua indikator yang belum maksimal terlaksana yaitu indikator variasi penekanan suara/memusatkan perhatiasn dan variiasi pemberian waktu karena adanya siswa yang susah diatur dan kurang percaya untuk bertanya ataupun menjawab pertanyaan guru. Pada variasi media pembelajaran belum maksimal dilaksanakan karena kurangnya sarana dan prasarana sekolah, guru tidak kreatif dalam membuat media atau memanfaatkan benda-benda lainnya untuk dijadikan media pelajaran yang sesuai dengan materi pelajaran. Sedangkan pada variasi pola interaksi belum maksimal dilaksanakan karena siswa kurang percaya diri untuk tampil di depan kelas

\section{Saran} berikut:

Berdasarkan kesimpulan di atas saran yang diberikan peneliti sebagai

1) Setiap guru harus dapat menguasai keterampilan mengajar terlebih lagi keterampilan mengadakan variasi agar baik guru maupun siswa terbantu dalam menyampaikan dan memahami pelajaran serta pembelajaran menjadi lebih menarik dan menyenangkan juga agar siswa tidak buta teknologi dan informasi, guru juga harus lebih sering memotivasi diri siswa dan melatih terus kepercayaan diri siswa untuk tampil di depan kelas.

2) Diharapkan agar pemerintah dapat menyalurkan bantun pada sekolah yang masih sangat minim fasilitasnya.

\section{DAFTAR PUSTAKA}

Djamarah, Syaiful Bahri. 2010. Guru dan Anak Didik dalam Interaksi Edukatif: Pedoman Bagi Mahasiswa PPL, Guru Alumni PLPG, PKG, dan PPG dalam Upaya Mengoptimalkan Aktivitas Anak Didik. Jakarta: Rineka Cipta.

Undang-Undang Nomor 20 Tahun 2003 Tentang Sistem Pendidikan Nasional.

Undang-Undang Nomor 14 Tahun 2005 Tentang Guru Dan Dosen..

Permatasari, Ayu Putri. 2016. "Kemampuan Guru Sekolah Dasar Dalam Mengadakan Variasi Pada Pembelajaran Tematik Di Gugus Imam Bonjol Kecamatan Purwodadi Kabupaten Grobogan". https://lib.unnes.ac.id/24194/1/1401412044.pdf, diakses pada tanggal 22 oktober 2018.

Sanjaya, Wina. 2006. Strategi Pembelajaran Berorientasi Standar Proses Pendidikan. Jakarta: Kencana.

Solihatin, Etin. 2013. Strategi Pembelajaran PPKn. Jakarta: Bumi Aksara.

Sugiyono, 2014. Memahami Penelitian Kualitatif. Bandung: ALFABETA 